\title{
Evaluation of The Total Laboratory Performance of Our Clinical Laboratory with Six-Sigma Method
}

\section{Klinik Laboratuvarımızın Toplam Kalite Performansının Altı-Sigma Metoduyla Değerlendirilmesi}

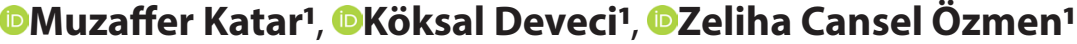 \\ 'Gaziosmanpasa University School of Medicine Department of Medical Biochemistry, Tokat, Turkey
}

\begin{abstract}
Aim:In order to evaluate the performance of the clinical laboratories, a quality measurement method, The Six-Sigma Methodology, is used. We aimed to evaluate the analytical performance of our clinical laboratory by using the internal and external quality control data of 28 analytes, and by calculating their process sigma values.

Material and Method: Sigma values of 28 analytes of our laboratory were determined from coefficient of variation (CV \%) and bias for 3 subsequent months from November 2018 to January 2019. If the sigma values are $>6$, between 3 and 6 , and $<3$, they are classified as world-class, good and un-acceptable, respectively.
\end{abstract}

Results: 6 (21\%) analytes; T Protein, Creatinin, Ca, Na, Cl, HbA1c; provided <3 sigma value, 1 (04\%) analyte; lipase; provided between 3-6 value and 11 (39\%) analytes; amylase, GGT, ALT, LDH, CRP, Lactate, BUN, Direct Bil., T Bil., CK and CK-MB; provided > 6 sigma value for both Internal Quality Control levels (IQC1 and IQC2) for three consecutive months, respectively.

Conclusions: In terms of Six-Sigma Metrics; our results were generally found as world-class or good. An appropriate quality control scheduling should be carried out for each test by using SixSigma Methodology in all clinical chemistry laboratories.

Keywords: Internal quality control, external quality control, six sigma, variation coefficient, standard deviation, bias
Öz

Amaç: Klinik laboratuvarların performansını değerlendirmek için bir kalite ölçüm yöntemi olan 'Altı Sigma Metodolojisi' kullanılmaktadır. Bu çalışmada, klinik laboratuvarımızın analitik performansını 28 analitin iç ve dış kalite kontrol verilerini kullanarak ve süreç sigma değerlerini hesaplayarak değerlendirmeyi amaçladık.

Gereç ve Yöntem: 28 analitin Sigma değerleri, Kasım 2018'den Ocak 2019'a kadar birbirini takip eden 3 ay boyunca varyasyon katsayıs (\% CV) ve bias kullanılarak belirlendi. Sigma değerleri > 6, 3 ila 6 arasındaysa ve $<3$ ise, sırasıyla; birinci sınıf veya dünya standartlarında, iyi ve kabul edilemez olarak değerlendirildi.

Bulgular: Art arda üç ay boyunca hem IQC1 hem de IQC2 seviyeleri için 6 (\% 21) analit; T Protein, Kreatinin, $\mathrm{Ca}, \mathrm{Na}, \mathrm{Cl}, \mathrm{HbA} 1 \mathrm{c},<3$ Sigma değeri sağladı, 1 (\% 04) analit; lipaz ise 3-6 Sigma değeri ve 11 (\% 39) analit; amilaz, GGT, ALT, LDH, CRP, Laktat, BUN, Direct Bil., T Bil., CK ve CK-MB ise $>6$ sigma değeri sağladı.

Sonuç: Sonuçlarımızın Altı-Sigma Metrikleri genel olarak dünya standartlarında veya iyi olarak bulunmuştur. Tüm klinik kimya laboratuvarlarında Altı-Sigma Metodolojisi kullanılarak her test için uygun bir kalite kontrol planlaması yapılmalıdır.

Anahtar Kelimeler: İç kalite kontrol, dı̧̧ kalite kontrol, altı sigma, varyasyon katsayısı, biyas

Corresponding (illetişim): Muzaffer Katar, Tokat Gaziosmanpasa University, School of Medicine, Department of Clinical Biochemistry, Tokat, Turkey 


\section{INTRODUCTION}

Clinical laboratories target to provide efficient and high quality service from the test request to the conclusion. In order to achieve efficiency and quality, errors occurring in laboratory processes must be determined and reset gradually. Only in this way, standards can be achieved that can be practiced and used medically. Quality levels of laboratory results depend on many factors, such as; the request and result management system used, the skill of the technician, and the analytical system used.

Quality management is defined as compliance with regulatory rules, accreditation rules and international standards. ${ }^{1}$ In total quality management, it is aimed to evaluate the process and identify possible error steps. The importance of quality control practices is understood when something goes bad. But they seem like a waste of time when things are going well. The main points of Internal Quality Control's (IQC) success are the ability to provide advanced planning, predict what can go wrong, warn when something goes wrong, ensure that a problem can be answered in a planned way and minimize damage.

In clinical laboratories, the analysis process performance evaluation covers all analytical phases; such as error percentages for pre-analytical phase, precision and reproducibility measurement (Bias, and SD) for the analytical phase, and delayed reports and panic value statements for the post-analytical phase. Analytical process performance evaluation can be accomplished by using the process sigma levels of internal and external quality control results.

Six sigma methodology is a quality management tool based on statistical calculations focused on process variables. ${ }^{2}$ Variations during process are thought to be the main source of errors. Process sigma level is the main indicator of this methodology. Poor quality costs determined from process sigma levels and defined as false probability (MFPO) in million opportunities provide an evaluation of process performance. By reducing poor quality costs, a significant improvements in the process can be obtained. ${ }^{3,4}$

In our work, it is targeted to evaluate 28 analytes of our clinical laboratory in terms of six sigma methodology.

\section{MATERIAL AND METHOD}

In our study, after taking approval of local ethics committee with the code of 18-KAEK-259, we investigated 28 analytes; glucose (Glu), alkaline phosphatase (ALP), amylase, gamma glutamyl transferase (GGT), alanine amino transferase (ALT), aspartate amino transferase (AST), lactate dehydrogenase $(\mathrm{LDH}), \quad$ C-Reactive Protein (CRP), blood urea nitrogen (BUN), creatinine, uric acid, lipase, ammoniac (NH3), lactate, D-Dimer, Total Bilirubin (T.Bil), Direct Bilirubin (D.Bil), creatinine kinase (CK), CK-MB, total protein (T.Prot.), Albumin (Alb), sodium $(\mathrm{Na})$, potassium $(\mathrm{K})$, chlorine $(\mathrm{Cl})$, magnesium (Mg), calcium (Ca), Phosphate (P), hemoglobin A1c (HbA1c) retrospectively for 3 consecutive months between November 2018 - January 2019 concerning six sigma methodology. We analyzed serum immuno assay tests by using the Cobas e 601 auto analyzer of Roche Diagnostics. We analyzed both levels of IQC materials on daily basis. We calibrate the instruments of our clinical laboratory systematically. We took throughput of IQC from laboratory data management system of Enlil LIS of our hospital.

After determining the SD and mean values of analytes, we calculated bias, \% CV, and sigma values of them. In Table I, we presented our laboratory mean and SD values of each test and the target means.

Coefficient of variation (CV\%), the uncertainty, is calculated from the Standard deviation and IQC data.

CV $(\%)=$ (average of SD / IQC data) $\times 100$.

The percentage difference of the average of the obtained results for each analyte of our laboratory from the target values in the annexes provided under the Roche control is termed as Bias.

Bias\%= [(our lab IQC data - average of target IQC data) / average of IQC Data target] $\times 100$

Total permissible error (TEa): TEa targets from a single source are used for Sigma metrics calculation (8). Table II highlights TEa values of analytes.

Analytical performance characteristic of an analyte is defined as 'Sigma Value'. CV (obtained from IQC data), Bias\% and TEa values are considered in Sigma metric calculation.

Sigma metric $(\mathrm{s})=($ TEa \%-Bias \%) $/$ CV \%

Sigma level $<3$ is regarded as poor performance. Indicator of a good performance ise $\geq 3$ sigma level. To be mentioned 'a world class performance' it must be more than 6 sigma levels (3).

\section{RESULTS}

Table 1 demonstrates comparison of the choosen analytes of our laboratory for both levels of IQC1 and IQC2.

In our study, CV \% values were calculated for consecutive three months as $<5$, except Lipase for QC1 and, Lipase and $\mathrm{NH} 3$ for QC2. Bias, CV\% and TEa values of the two levels of QC for all analytes are shown in Table $\mathbf{2}$.

In Table 3, calculated sigma values of all analytes are shown and the maximum value of all was figured out as 54.17.

For both IQC levels, during three months, our $7 / 8,11 / 8$, $11 / 10$ parameters provided $<3$ sigma metrics, $6 / 6,3 / 3,5 / 6$ parameters provided between 3-6 sigma metrics and 14/14, 14 / 14, 12/12 parameters provided $>6$ sigma metric values, respectively. Table 4 shows the sigma levels of analytes. 
Table 1. The target mean, laboratory mean and SD values of each test.

\begin{tabular}{|c|c|c|c|c|c|c|c|c|}
\hline \multirow{3}{*}{ Assay Name } & \multicolumn{4}{|c|}{ IQC1 } & \multicolumn{4}{|c|}{ IQC2 } \\
\hline & \multirow{2}{*}{$\begin{array}{l}\text { Target } \\
\text { Mean }\end{array}$} & \multirow{2}{*}{$\begin{array}{c}\text { November } \\
\text { Lab Mean } \\
\text { 土SD }\end{array}$} & \multirow{2}{*}{$\begin{array}{l}\text { December } \\
\text { Lab Mean } \\
\text { 土SD }\end{array}$} & \multirow{2}{*}{$\begin{array}{c}\text { January } \\
\text { Lab Mean } \\
\text { 土SD }\end{array}$} & \multirow{2}{*}{$\begin{array}{l}\text { Target } \\
\text { Mean }\end{array}$} & \multirow{2}{*}{$\begin{array}{l}\text { November } \\
\text { Lab Mean } \\
\text { 土SD }\end{array}$} & \multirow{2}{*}{$\begin{array}{l}\text { December } \\
\text { Lab Mean } \\
\pm \text { SD }\end{array}$} & \multirow{2}{*}{$\begin{array}{l}\text { January } \\
\text { Lab Mean } \\
\text { 土SD }\end{array}$} \\
\hline & & & & & & & & \\
\hline Glucose & 101 & $105.76 \pm 1.25$ & $104.21 \pm 3.12$ & $103.17 \pm 2.8$ & 236 & $237.57 \pm 3.66$ & $237.61 \pm 6.02$ & $238.03 \pm 5.63$ \\
\hline ALP & 92.1 & $90.63 \pm 2.18$ & $91.7 \pm 2.87$ & $92.85 \pm 2.56$ & 230 & $223.31 \pm 5.47$ & $221.25 \pm 5.32$ & $222.23 \pm 6.04$ \\
\hline Amylase & 80.5 & $80.97 \pm 1.07$ & $80.69 \pm 1.15$ & $81.63 \pm 1.41$ & 195 & $189.06 \pm 2.21$ & $192.34 \pm 2.3$ & $197.28 \pm 2.36$ \\
\hline GGT & 53.05 & $54.56 \pm 1.48$ & $55.05 \pm 1.28$ & $55.61 \pm 0.97$ & 241 & $242.97 \pm 4.33$ & $247.35 \pm 4.96$ & $250.37 \pm 3.59$ \\
\hline AST & 46.1 & $46.76 \pm 1.16$ & $47.01 \pm 1.32$ & $46.54 \pm 1.22$ & 138.5 & $137.59 \pm 2.89$ & $141.28 \pm 3.63$ & $144.84 \pm 3.96$ \\
\hline ALT & 45.3 & $44.38 \pm 1.1$ & $44.56 \pm 1.2$ & $45.75 \pm 1.47$ & 117.5 & $111.25 \pm 2.01$ & $110.15 \pm 2.74$ & $115.59 \pm 4.71$ \\
\hline LDH & 162 & $164.78 \pm 2.62$ & $165 \pm 2.28$ & $164.31 \pm 2.61$ & 297 & $292.22 \pm 3.92$ & $293.59 \pm 4.92$ & $300.34 \pm 3.3$ \\
\hline Posphate & 4.25 & $4.35 \pm 0.08$ & $4.35 \pm 0.21$ & $4.42 \pm 0.1$ & 7.735 & $7.58 \pm 0.11$ & $7.81 \pm 0.13$ & $8.4 \pm 0.2$ \\
\hline CRP & 8.06 & $7.5 \pm 0.11$ & $7.56 \pm 0.23$ & $7.55 \pm 0.13$ & 39.2 & $35.05 \pm 0.9$ & $35.93 \pm 1.3$ & $36.42 \pm 0.98$ \\
\hline T. Protein & 4.71 & $4.73 \pm 0.08$ & $4.78 \pm 0.06$ & $4.77 \pm 0.07$ & 7.515 & $7.6 \pm 0.13$ & $7.58 \pm 0.09$ & $7.6 \pm 0.09$ \\
\hline Albumin & 3.07 & $2.95 \pm 0.08$ & $2.98 \pm 0.08$ & $3.06 \pm 0.11$ & 4.83 & $4.77 \pm 0.09$ & $4.72 \pm 0.08$ & $4.79 \pm 0.16$ \\
\hline Creatinine & 1.07 & $1.09 \pm 0.04$ & $1.1 \pm 0.05$ & $1.12 \pm 0.04$ & 3.975 & $4.13 \pm 0.14$ & $4.07 \pm 0.14$ & $4.01 \pm 0.14$ \\
\hline Uric Acid & 4.7 & $4.82 \pm 0.13$ & $4.68 \pm 0.07$ & $4.81 \pm 0.13$ & 9.835 & $9.49 \pm 0.18$ & $9.83 \pm 0.16$ & $10.58 \pm 0.29$ \\
\hline Lipase & 45.3 & $45.9 \pm 3.96$ & $45.91 \pm 3.46$ & $45.88 \pm 3.43$ & 100.35 & $96.52 \pm 7.31$ & $100.02 \pm 7.44$ & $100.06 \pm 6.76$ \\
\hline $\mathrm{NH} 3$ & 217 & $208.95 \pm 7.34$ & $209.69 \pm 9.81$ & $213.67 \pm 6.65$ & 58.5 & $57.44 \pm 5.49$ & $57.4 \pm 4.6$ & $60.65 \pm 4.74$ \\
\hline Lactate & 1.66 & $1.72 \pm 0.04$ & $1.72 \pm 0.03$ & $1.7 \pm 0.02$ & 3.575 & $3.46 \pm 0.07$ & $3.62 \pm 0.06$ & $3.83 \pm 0.06$ \\
\hline BUN & 18.2 & $18.71 \pm 0.39$ & $18.38 \pm 0.33$ & $18.23 \pm 0.39$ & 54.45 & $55.58 \pm 1.13$ & $55.63 \pm 1.01$ & $55.84 \pm 1.12$ \\
\hline D-Dimer & 0.815 & $0.82 \pm 0.03$ & $0.81 \pm 0.03$ & $0.82 \pm 0.06$ & 3.8 & $3.79 \pm 0.05$ & $3.77 \pm 0.03$ & $3.84 \pm 0.13$ \\
\hline Calcium & 8.86 & $9.07 \pm 0.13$ & $9.06 \pm 0.13$ & $9.1 \pm 0.11$ & 13.6 & $13.88 \pm 0.2$ & $13.83 \pm 0.17$ & $13.95 \pm 0.18$ \\
\hline Direct Bil. & 1.02 & $0.95 \pm 0.02$ & $0.97 \pm 0.03$ & $0.98 \pm 0.02$ & 2.6 & $2.4 \pm 0.06$ & $2.49 \pm 0.06$ & $2.61 \pm 0.04$ \\
\hline Total Bil. & 0.989 & $0.97 \pm 0.03$ & $0.98 \pm 0.03$ & $1 \pm 0.03$ & 3.935 & $3.78 \pm 0.09$ & $3.82 \pm 0.08$ & $4.03 \pm 0.09$ \\
\hline $\mathrm{Mg}$ & 2.09 & $2.05 \pm 0.04$ & $2.05 \pm 0.07$ & $2.04 \pm 0.06$ & 3.35 & $3.21 \pm 0.05$ & $3.31 \pm 0.08$ & $3.43 \pm 0.07$ \\
\hline CK & 161 & $156.03 \pm 1.99$ & $158.75 \pm 3.3$ & $159.59 \pm 3.25$ & 282 & $263.86 \pm 3.48$ & $274.59 \pm 4.13$ & $294.14 \pm 5.11$ \\
\hline CK-MB & 43.6 & $41.99 \pm 0.77$ & $42.25 \pm 0.21$ & $42 \pm 1.01$ & 94.45 & $88.78 \pm 1.62$ & $89.18 \pm 1.44$ & $92.41 \pm 1.26$ \\
\hline $\mathrm{Na}$ & 111 & $112.12 \pm 2.31$ & $111.47 \pm 1.52$ & $112.2 \pm 2.8$ & 136 & $135.51 \pm 3.43$ & $134.81 \pm 1.74$ & $138.44 \pm 2.26$ \\
\hline K & 3.77 & $3.8 \pm 0.08$ & $3.76 \pm 0.08$ & $3.78 \pm 0.08$ & 6.945 & $6.79 \pm 0.15$ & $6.89 \pm 0.08$ & $7.21 \pm 0.12$ \\
\hline $\mathrm{Cl}$ & 80.6 & $81.32 \pm 2.3$ & $79.83 \pm 1.84$ & $81.05 \pm 1.57$ & 108 & $108.5 \pm 2.42$ & $106.66 \pm 1.81$ & $108.82 \pm 1.94$ \\
\hline $\mathrm{HbA1C}$ & 10.4 & $5.49 \pm 0.12$ & $10.49 \pm 0.18$ & $10.48 \pm 0.16$ & 5.63 & $10.5 \pm 0.12$ & $5.58 \pm 0.1$ & $5.55 \pm 0.08$ \\
\hline
\end{tabular}

\section{DISCUSSION}

One of the most important quality control analyzes used in quality and performance evaluation is 'The Six Sigma Method' and is carried out by statistical calculations. ${ }^{5}$ The Sigma Metrics provide quantitative comparison of various autoanalyzers, laboratories and methods throughout the world. ${ }^{6}$ If six standard deviations between the average of an analyte and its upper and lower margins can be maintained, errors can be reduced in the laboratory. ${ }^{7}$

TEa is the tolerance limits of a clinical laboratory. If the TEa value is less than the difference between the real analytical concentration of the patient samples and the reported concentration, the result is unreliable. ${ }^{7}$ The degree of diversity of a test used is termed as TEa and is used in clinical decisions managing further treatment or follow-up.

$\mathrm{CV} \%$ to determine the diversity of a test; expressed as a percentage of the ratio of change to average. The $\leq 5 \%$ $\mathrm{CV}$ value indicates that the analytical method or analyzer has good performance, while the $\geq 10 \%$ CV value shows inadequate performance. ${ }^{9}$
Verma et al..$^{5}$ calculated the averages of $\% \mathrm{CVs}$ of $2^{\text {nd }}$ and $3^{\text {rd }}$ level IQCs for 16 parameters from January 2017 to December 2017. The mean of CVs for level 2 was between $2.12 \%$ (albumin) and $5.42 \%$ (creatinine), and for level 3 , it was between $2 \%$ (albumin) and 3.62\% (HDL-cholesterol). The CV average of all parameters was below $5 \%$, with very good accuracy.

For level 2 IQC, 11 (68.5\%) out of 16 parameters failed to meet sigma metrics. Five of them failed to meet a minimum of quality performance with less than 3 , and the other six parameters barely met minimal performance with 3 to 6 . For level 3 IQC, 8 (50\%) six-parameter sigma quality performance failed. Three of them had metrics below 3 , while 5 had between 3 and 6 . The TEAs of all analytes were lower than those of predetermined TEAs except AST and ALT.

In a study on an architect i2000 SR autoanalizer, carried out by Litten J et al. ${ }^{6}$ control CVs of CEA, total PSA, FT3, FT4, TSH, ferritin, $\mathrm{FSH}$ and vitamin $\mathrm{B} 12$ immune tests ranged between $1.34 \%$ and $18.87 \%$, and most of the CV values were below $5 \%$. In this study, pathological and normal IQC levels \% CV values for tests including CEA, ferritin, FSH, FT3 were found $<5$ for 
Table 2. TEa, bias and CV values of the two levels of quality control for the assays.

\begin{tabular}{|c|c|c|c|c|c|c|c|c|c|c|c|c|c|}
\hline \multirow{2}{*}{ Assay Name } & \multirow{2}{*}{$\begin{array}{l}\text { TEa } \\
(\%)\end{array}$} & \multicolumn{6}{|c|}{ IQC1 } & \multicolumn{6}{|c|}{ IQC2 } \\
\hline & & \multicolumn{2}{|c|}{ November } & \multicolumn{2}{|c|}{ December } & \multicolumn{2}{|c|}{ January } & \multicolumn{2}{|c|}{ November } & \multicolumn{2}{|c|}{ December } & \multicolumn{2}{|c|}{ January } \\
\hline Glucose & 6.96 & 1.18 & 4.71 & 2.99 & 3.18 & 2.71 & 2.15 & 1.54 & 2.40 & 2.53 & 0.68 & 2.36 & -0.82 \\
\hline Amylase & 14.6 & 1.33 & 0.58 & 1.43 & 0.24 & 1.73 & 1.40 & 1.17 & -0.49 & 1.20 & -1.36 & 1.20 & -1.36 \\
\hline GGT & 22.11 & 2.71 & 1.98 & 2.33 & 2.90 & 1.75 & 3.94 & 1.78 & 0.82 & 2.01 & 2.63 & 1.43 & 3.89 \\
\hline LDH & 11.4 & 1.59 & 1.72 & 1.38 & 1.85 & 1.59 & 1.43 & 1.34 & 0.07 & 1.68 & -1.15 & 1.10 & -0.55 \\
\hline Posphate & 10.11 & 1.82 & 2.29 & 4.92 & 2.34 & 2.16 & 3.95 & 1.47 & 2.69 & 1.68 & 0.92 & 2.41 & 3.80 \\
\hline CRP & 66.54 & 1.43 & -6.97 & 3.03 & -6.17 & 1.75 & -6.28 & 2.56 & -8.95 & 3.62 & -8.34 & 2.70 & -8.73 \\
\hline Total Protein & 3.63 & 1.75 & 0.35 & 1.22 & 1.43 & 1.46 & 1.32 & 1.75 & 0.56 & 1.14 & 0.89 & 1.24 & 1.78 \\
\hline Albumin & 4.07 & 2.65 & -4.01 & 2.77 & -2.84 & 3.71 & -0.45 & 1.85 & -2.72 & 1.66 & -2.23 & 3.38 & 0.58 \\
\hline $\mathrm{NH} 3$ & 29.6 & 3.51 & -3.71 & 4.68 & -3.37 & 3.11 & -1.08 & 9.56 & -1.82 & 8.01 & -1.88 & 7.82 & 3.68 \\
\hline Lactate & 30.4 & 2.36 & 3.55 & 1.87 & 3.33 & 1.44 & 2.33 & 2.08 & 2.29 & 1.73 & 1.35 & 1.59 & 1.46 \\
\hline BUN & 15.55 & 2.10 & 2.80 & 1.79 & 0.97 & 2.12 & 0.16 & 2.03 & 2.36 & 1.81 & 2.17 & 2.00 & 2.26 \\
\hline D-Dimer & 28.04 & 3.19 & 2.46 & 3.36 & -0.38 & 6.69 & 0.37 & 1.27 & -0.18 & 0.88 & -0.69 & 3.40 & 1.00 \\
\hline Calcium & 2.55 & 1.42 & 2.35 & 1.40 & 2.24 & 1.26 & 2.75 & 1.43 & 2.07 & 1.22 & 1.66 & 1.31 & 2.58 \\
\hline Direct Bil. & 44.5 & 2.05 & -6.86 & 3.19 & -4.90 & 2.31 & -4.13 & 2.33 & -4.54 & 2.32 & -4.17 & 1.68 & -3.13 \\
\hline Total Bil. & 26.94 & 3.40 & -2.34 & 3.31 & -1.35 & 3.00 & 0.62 & 2.28 & -1.36 & 2.17 & -3.05 & 2.20 & -0.16 \\
\hline $\mathrm{Mg}$ & 4.8 & 1.98 & -2.09 & 3.52 & -2.15 & 2.99 & -2.55 & 1.47 & -0.55 & 2.33 & -1.28 & 2.14 & -1.08 \\
\hline CK & 30.3 & 1.28 & -3.08 & 2.08 & -1.40 & 2.03 & -0.88 & 1.32 & -1.54 & 1.50 & -2.63 & 1.74 & -0.63 \\
\hline CK-MB & 24.1 & 1.84 & -3.70 & 0.50 & -3.10 & 2.40 & -3.66 & 1.82 & -5.05 & 1.62 & -5.58 & 1.36 & -3.14 \\
\hline
\end{tabular}

every three months. CV values of other tests were found as $<5$ or $>5$ for 3 months, but did not exceed $10 \%$. Inconsistency of the IQC through calibration preparation, transport or storage, and mistakes during sample use $d$ by laboratory technicians may be the causes of $\mathrm{CV} \%$ and bias variability.

In our study, average CV \% of QC1 excluding Lipase; it was calculated as $2.42 \%$ ranging between $0.50 \%$ (CK-MB) and $6.69 \%$ (D-Dimer). For QC2, the average CV \% value excluding Lipase and $\mathrm{NH} 3$ was calculated as $1.98 \%$ ranging between $0.88 \%$ (D-Dimer) and 4.08\% (ALT). For both levels, for Lipase, they were calculated as 7.88 and 7.26 , respectively, and 8.46 for the second level for $\mathrm{NH}$.

For Glu, ALP, Amylase, GGT, ALT, AST, LDH, CRP, BUN, Creatinine, Uric Acid, Lactate, D-Dimer, T. Bil, D. Bil, CK, CK-MB, T. Prot, Alb, $\mathrm{Na}, \mathrm{K}, \mathrm{Cl}, \mathrm{Mg}, \mathrm{Ca}, \mathrm{P}, \mathrm{HbA} 1 \mathrm{c}$ tests, CV \% values of both IQC levels were calculated as $<5 \%$ for 3 consecutive months. Lipase was determined as $>5 \%$ of both IQC levels for every three months. For $\mathrm{NH} 3, \mathrm{CV} \%$ values of IQC2 levels were found to be $>5 \%$ for every three months. However, no value was $>10 \%$.

Evaluating the analytical stage, optimization of laboratory tests' quality measurements and quality control rules based on sigma values are defined as Six Sigma Methodology. IQC applications must be specific for tests and must be created in a harmony with the sigma values of each test. The analysis of analytical processes before and after analytics should be done to evaluate the overall performance of the laboratory.

Ercan et al. ${ }^{7}$ determined sigma values as 4.38 / 4.01 and 8.12 / 9.7 for first and second level IQC for vitamin B12 and folate tests in Beckman Coulter UniCel ${ }^{\oplus}$ Dxl 800 Immuno assay System autoanalyst, respectively.

In their study, Nanda et al. ${ }^{8}$ found sigma metric values for glucose, cholesterol and urea as 3.2, 2.2, 5.2, respectively. Sigma metric values for triglycerides and SGOT were found to be greater than 6 .

James O Westgard et al. ${ }^{9}$ found that sigma metric values for glucose and total cholesterol were in a range between 2.9 to 3.3 , and 2.9 to 3.0, respectively. For ALP, while the value of sigma metrics was greater than 6 , it was between 3.1 and 5.9 in a study by Bhawna Singh et al. ${ }^{10}$ Sigma metric values for creatinine were found to be 3.1. In a study by Carl Garber ${ }^{11}$, 
Table 3. The sigma metrics for 3 months and overall sigma metrics for the assays.

\begin{tabular}{|c|c|c|c|c|c|c|}
\hline \multirow[b]{2}{*}{ Assay Name } & \multicolumn{2}{|c|}{ November } & \multicolumn{2}{|c|}{ December } & \multicolumn{2}{|c|}{ January } \\
\hline & $\begin{array}{l}\text { IQC1 sigma } \\
\text { metrics }\end{array}$ & $\begin{array}{l}\text { IQC2 sigma } \\
\text { metrics }\end{array}$ & $\begin{array}{l}\text { IQC1 sigma } \\
\text { metrics }\end{array}$ & $\begin{array}{l}\text { IQC2 sigma } \\
\text { metrics }\end{array}$ & $\begin{array}{l}\text { IQC1 sigma } \\
\text { metrics }\end{array}$ & $\begin{array}{c}\text { IQC2 sigma } \\
\text { metrics }\end{array}$ \\
\hline Glucose & 1.90 & 2.96 & 1.26 & 2.48 & 1.77 & 3.29 \\
\hline ALP & 5.66 & 6.79 & 3.99 & 6.59 & 4.07 & 5.04 \\
\hline Amylase & 10.56 & 12.93 & 10.07 & 13.35 & 7.65 & 13.35 \\
\hline GGT & 7.42 & 11.95 & 8.26 & 9.70 & 10.38 & 12.71 \\
\hline AST & 6.16 & 7.39 & 5.24 & 5.72 & 6.00 & 5.11 \\
\hline ALT & 11.90 & 16.53 & 10.77 & 13.54 & 8.23 & 7.84 \\
\hline LDH & 6.08 & 8.43 & 6.91 & 7.49 & 6.28 & 10.88 \\
\hline Posphate & 4.31 & 5.05 & 1.58 & 5.47 & 2.86 & 2.62 \\
\hline CRP & 51.51 & 29.55 & 23.97 & 20.67 & 41.71 & 27.93 \\
\hline Total Protein & 1.87 & 1.76 & 1.79 & 2.41 & 1.58 & 1.50 \\
\hline Albumin & 3.05 & 3.66 & 2.50 & 3.79 & 1.22 & 1.03 \\
\hline Creatinine & 1.75 & 2.35 & 1.33 & 1.90 & 0.99 & 1.42 \\
\hline Uric Acid & 5.00 & 5.00 & 8.04 & 7.36 & 3.60 & 3.69 \\
\hline Lipase & 4.24 & 5.30 & 4.84 & 5.14 & 4.90 & 5.89 \\
\hline $\mathrm{NH} 3$ & 9.48 & 3.29 & 7.05 & 3.93 & 9.86 & 3.32 \\
\hline Lactate & 11.37 & 13.52 & 14.50 & 16.77 & 19.50 & 18.19 \\
\hline BUN & 6.08 & 6.48 & 8.14 & 7.38 & 7.24 & 6.65 \\
\hline D-Dimer & 8.01 & 22.13 & 8.46 & 32.74 & 4.14 & 7.94 \\
\hline Calcium & 0.14 & 0.34 & 0.22 & 0.73 & -0.16 & -0.02 \\
\hline Direct Bil. & 25.08 & 21.03 & 15.47 & 21.02 & 21.02 & 28.29 \\
\hline Total Bil. & 8.61 & 12.39 & 8.53 & 13.82 & 8.76 & 12.30 \\
\hline $\mathrm{Mg}$ & 3.47 & 3.65 & 1.98 & 2.60 & 2.45 & 2.75 \\
\hline CK & 26.16 & 24.13 & 15.23 & 21.89 & 15.33 & 17.80 \\
\hline CK-MB & 15.07 & 16.01 & 54.17 & 18.33 & 11.56 & 20.00 \\
\hline $\mathrm{Na}$ & -0.14 & 0.14 & 0.23 & 1.24 & -0.14 & -0.20 \\
\hline K & 2.25 & 2.26 & 2.85 & 5.50 & 2.40 & 2.77 \\
\hline $\mathrm{Cl}$ & 0.22 & 0.46 & 1.07 & 1.62 & 0.41 & 0.41 \\
\hline $\mathrm{HbA1C}$ & 2.43 & 1.86 & 1.25 & 2.15 & 1.41 & 2.99 \\
\hline
\end{tabular}

sigma metric values of creatinine were found to be 6.0.

For guiding QC strategy design Sigma values are very useful. For high sigma process, to detect any out-of-control situation that may cause a significant risk for the emergence of unreliable results, designing a QC procedure is relatively easy. ${ }^{8}$ In the study of Nar et al. ${ }^{12}$, the sigma metrics of Folate, $\mathrm{LH}$, PRL, TPSA, TSH and vitamin B12 were above the average of 6.0 for 3 months. Therefore, for these parameters, they did not need any changes in the QC protocol and patient results were released. For parameters such as CA 19-9, CA 15-3, CEA, ferritin, PTH, FT3, cortisol, FSH and testosterone, the sigma metric values were between 3 and 6 on average.

Gulbahar et al. ${ }^{13}$ conducted a study on Roche Cobas e 602 autoanalyser and the two level IQC sigma values of TSH, FT3 and FT4 were compared with two immunoassay analyzers. When the sigma values were calculated, it was found as 'World class' and 'unacceptable' for TSH and FT4, respectively. In both analyzers, FT3 was found as 'unacceptable' and 'good' for the two levels IQC of the first analyzer and the second level of the second analyzer, respectively.
Differences in sigma values of the study of Nar et al. ${ }^{12}$ with other studies may be due to autoanalysis, quality control materials, or pre-analytical and post-analytical conditions. They conducted that sigma metric values are required to determine the design and implementation of IQC acceptability criteria and rational control design according to sigma values with the help of Westgard Operational Spesifications Chart (OPSpecschart) in the clinical biochemistry laboratory. ${ }^{8}$

The errors during the calibrator preparation can be the IQC malfunction during transportation or storage, and mistakes during sample preperation by laboratory technicians. For better bias and $\mathrm{CV} \%$, a protocol should be established for the transportation and division of the IQC and calibrator samples to avoid interventions caused by laboratory technicians through the experiment.

Nanda et al. ${ }^{15}$, in their study for routine biochemistry tests found six sigma values; > 6 for AST, ALT, ALP, total bilirubin and uric acid tests; in the range of 3-6 for glu, creat, triglyceride tests; $<3$ for urea, Alb, T.prot., total cholesterol and chlorine tests. 
Table 4. The distribution of groups and tests according to sigma values.

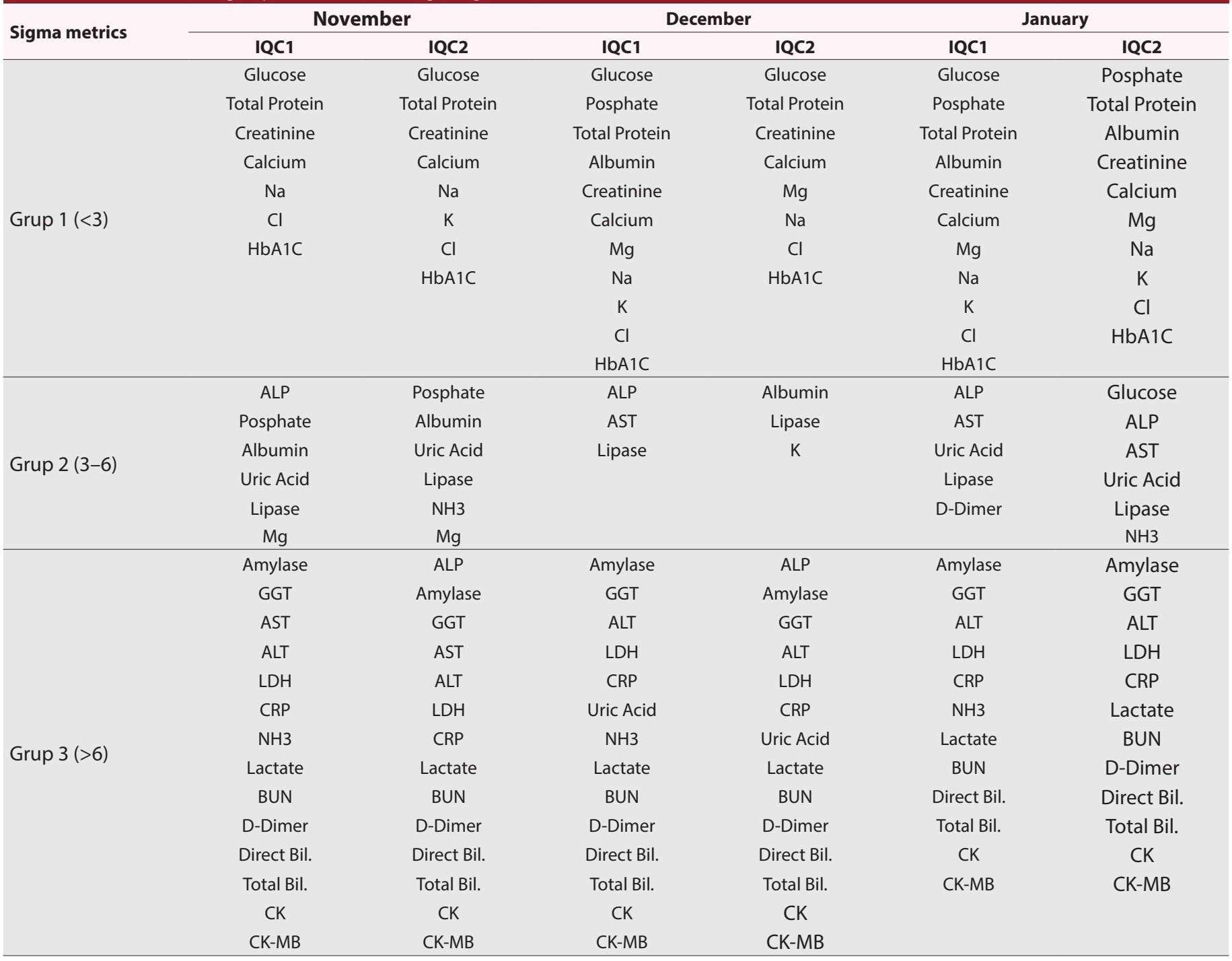

Chaudhary et al. ${ }^{16}$ defined sigma values in their study for routine biochemistry tests in a 4-month period; > 3 for Glu, ALP, T prot., Triglyceride, HDL-cholesterol, amylase and uric acid; it was found less than $<3$ for AST, ALT and total cholesterol.

In a study by Adiga et al. ${ }^{14}$, sigma values of ALT, direct bilirubin, total bilirubin, calcium, creat, urea (D1) and AST, direct bilirubin, urea (D2) were <3; AST, Glu, cholesterol, uric acid, T prot. (D1) and ALT, calcium, cholesterol, Creat, Glu, total bilirubin (D2) were 3-6; Alb, ALP, triglyceride, HDL (D1) and Alb, ALP, HDL, T. Prot., TG, uric acid (D2) were $>6$.

In their study, Nar et al. ${ }^{12}$ evaluated the laboratory performances of immuno assay tests on the Cobas e 601 analyzer (Roche Diagnostics, Germany) for 3 months from June 2015 to August 2015. TSH was determined to be $>6$ sigma in both levels of quality control during three month. The sigma value for FT3 was between 3 and 6 for the first level for 3 months, while for the second level that was $>6$ and between 3 and 6 for three months, respectively. Mean sigma values of
TSH, FT4 and FT3 were found to be 13.06 / 16.13, 3.97 / 3.69, 3.75 / 6.57 for both levels, respectively, for the three-months. According to these results, TSH was found as 'World standards' for both levels; FT3 was found as 'good' and 'World standards' for the first and second levels, and FT4 was found as 'good' for both levels. Sigma values for both IQC levels for AFP, cortisol, ferritin and total PSA tests, 6.98 / 11.17, 4.15 / 6,33, 6,77 / 7,35, 13,62 / 13,42 were found. Vitamin B12 and folate tests were found to be 12.52 / 10.67, 7.89 / 9.83 in sigma values for both IQC levels.

Six (21\%) parameters; T Protein, Creatinin, $\mathrm{Ca}, \mathrm{Na}, \mathrm{Cl}, \mathrm{HbA} 1 \mathrm{c}$; provided < 3 sigma value, 1 (04\%) parameter; lipase; provided between 3-6 value and 11 (39\%) parameters; amylase, GGT, ALT, LDH, CRP, Lactate, BUN, Direct Bil., T Bil., CK and CK-MB; provided > 6 sigma value for both IQC1 and IQC2 levels for three months, respectively

T. Protein, $\mathrm{Ca}, \mathrm{Na}, \mathrm{Cl}, \mathrm{HbA} 1 \mathrm{c}$ produced <3 sigma value for every three months and for both IQC levels. For these parameters 
necessity of implementing a very strict internal and external quality control and corrective activities appeared. A 3-6 sigma value was determined for the lipase and QC monitoring was stil acceptable for this parameter, although it was stil within acceptable limits. $>6$ sigma values were observed for Amylase, GGT, ALT, LDH, CRP, Lactate, BUN, T. Bil, D. Bil., CK, CK-MB. Therefore, for these parameters, we did not need any changes in the QC protocol and patient results were released.

As a result of our study, calibrations of the parameters with low six sigma level are performed more frequently in our laboratories and the number of IQCs per day has been increased.

\section{CONCLUSION}

Laboratories need to design their own quality control (QC) protocols to meet the quality wanted. Laboratory errors can be reduced by preserving analyte mean and six Standard deviations between its upper and lower limits.

\section{ETHICAL DECLARATIONS}

Ethics Committee Approval: We took approval of Tokat Gaziosmanpasa University, Deanery of Medical Faculty, Clinical Researches Ethics Committee at 20.11.2018 with the code of 18-KAEK-259.

Informed Consent: All patients signed the free and informed consent form.

Referee Evaluation Process: Externally peer-reviewed.

Conflict of Interest Statement: The authors have no conflicts of interest to declare.

Financial Disclosure: The authors declared that this study has received no financial support.

Author Contributions: All of the authors declare that they have all participated in the design, execution, and analysis of the paper, and that they have approved the final version.

Acknowledgements: We all authors thank to our all laboratory staff for their great contribution during IQC proceses, and information process personel who supplied needed data of our hospital.

\section{REFERENCES}

1. Levey S, Jennings E. The use of control charts in the clinical laboratory. Am J Clin Pathology. 1950;20(11_ts):1059-66.

2. Derleme Ç. Laboratuvar tıbbında altı-sigma kalite yönetimi. Türk Biyokimya Dergisi [Turkish Journal of Biochemistry-Turk J Biochem]. 2005;30(4):272-8

3. Westgard JO. Six sigma quality design and control: Westgard QC, Incorporated; 2006.

4. Pande N. Cavanagh, The Six Sigma Way. McGraw Hill; 2000.

5. Verma M, Dahiya K, Ghalaut VS, Dhupper V. Assessment of quality control system by sigma metrics and quality goal index ratio: A roadmap towards preparation for NABL. World J Methodol 2018;8(3):44.
6. Litten J, Lynne N, Johnson K, Shih J. Evaluation of technopath controls on the architect family of instruments. Clin Chem Lab Med. 2015;53:S1S1450.

7. Ercan M, Bogdaycloğlu N, Akbulut E, Oğuz E, Topçuoğlu C, Yllmaz F. Assessment Of The Analytic Performance For Immunassay Tests With Six Sigma Methodology: T425. Clin Chem Laboratory Med 2015;53.

8. Nanda SK, Ray L. Quantitative application of sigma metrics in medical biochemistry. J Clin Diagn Res2013;7(12):2689.

9. Westgard JO, Westgard SA. An assessment of $\sigma$ metrics for analytic quality using performance data from proficiency testing surveys and the CLIA criteria for acceptable performance. Am J Clin Pathol. 2006;125(3):343-54.

10. Singh B, Goswami B, Gupta VK, Chawla R, Mallika V. Application of sigma metrics for the assessment of quality assurance in clinical biochemistry laboratory in India: a pilot study. Indian J Clin Biochem 2011;26(2):131-5.

11. Garber C. Six Sigma: its role in the clinical laboratory. Clin Lab News. 2004;4:10-4.

12. Nar R, Emekli DI. The evaluation of analytical performance of immunoassay tests by using six-sigma method. J Med Biochem 2017;36(4):301-8.

13. Gulbahar O, Arslan B, Sen B, Cingirt M, Yılmaz S. Evaluation of thyroid function tests in our laboratory by using six sigma analysis. Turk J Biochem 2015;40(S1).

14. Adiga US, Preethika A, Swathi K. Sigma metrics in clinical chemistry laboratory-A guide to quality control. Al Am een J Med Sci. 2015;8(4):2817.

15. Nanda SK, Ray L. Quantitative application of sigma metrics in medical biochemistry. J Clin Diagn Res 2013;7(12):2689-91.

16. Chaudhary NG, Patani SS, Sharma H, Maheshwari A, Jadhav PM, Maniar MA. Application of six sigma for the quality assurance in clinical biochemistry laboratory-a retrospective study. Int J Res Med. 2013;2(3):17-20. 